\title{
Adenosine and inosine exert cytoprotective effects in an in vitro model of liver ischemia-reperfusion injury
}

\author{
KATALIN MÓDIS ${ }^{1,2}$, DOMOKOS GERŐ ${ }^{1,2}$, RITA STANGL ${ }^{3}$, OLIVÉR ROSERO ${ }^{3}$, ATTILA SZIJÁRTÓ ${ }^{3}$, \\ GÁBOR LOTZ ${ }^{4}$, PETRA MOHÁCSIK ${ }^{2}$, PETRA SZOLECZKY ${ }^{1,2}$, CIRO COLETTA $^{1}$ and CSABA SZABÓ ${ }^{1,2}$ \\ ${ }^{1}$ Department of Anesthesiology, University of Texas Medical Branch, Galveston, TX 77555, USA; \\ ${ }^{2}$ CellScreen Applied Research Center, ${ }^{3}$ st Department of Surgery and ${ }^{4}$ 2nd Department \\ of Pathology, Semmelweis University Medical School, Budapest, Hungary
}

Received August 30, 2012; Accepted October 5, 2012

DOI: $10.3892 /$ ijmm.2012.1203

\begin{abstract}
Liver ischemia represents a common clinical problem. In the present study, using an in vitro model of hepatic ischemia-reperfusion injury, we evaluated the potential cytoprotective effect of the purine metabolites, such as adenosine and inosine, and studied the mode of their pharmacological actions. The human hepatocellular carcinoma-derived cell line HepG2 was subjected to combined oxygen-glucose deprivation (COGD; 0-14-24 h), followed by re-oxygenation (0-4-24 h). Adenosine or inosine (300-1,000 $\mu \mathrm{M})$ were applied in pretreatment. Cell viability and cytotoxicity were measured by the 3-(4,5-dimethyl-2-thiazolyl)-2,5-diphenyl$2 \mathrm{H}$-tetrazolium bromide and lactate dehydrogenase methods, respectively. The results showed that both adenosine and inosine exerted cytoprotective effects, and these effects were not related to receptor-mediated actions, since they were not prevented by selective adenosine receptor antagonists. On the other hand, the adenosine deaminase inhibitor erythro-9(2-hydroxy-3-nonyl) adenine hydrochloride (EHNA, $10 \mu \mathrm{M}$ ) markedly and almost fully reversed the protective effect of adenosine during COGD, while it did not influence the cytoprotective effect of inosine in the same assay conditions. These
\end{abstract}

Correspondence to: Professor Csaba Szabo, Department of Anesthesiology, University of Texas Medical Branch, 601 Harborside Drive, Building 21, Room 3.202D, Galveston, TX 77555, USA

E-mail: szabocsaba@aol.com

Abbreviations: ABT 702, 4-amino-5-(3-bromophenyl)-7-(6morpholino-pyridin-3-yl)pyrido[2,3-d]pyrimidine, $2 \mathrm{HCl}$; CDPX, 8-cyclopentyl-1,3-dipropylxanthine; CSC, 8-(3-chlorostyryl) caffeine; COGD, combined oxygen-glucose deprivation; DMEM, Dulbecco's modified Eagle's medium; DMSO, dimethylsulfoxide; EHNA, erythro-9-(2-hydroxy-3-nonyl) adenine hydrochloride; I-R injury, ischemia-reperfusion injury; LDH, lactate dehydrogenase; MTT, 3-(4,5-dimethyl-2-thiazolyl)-2,5-diphenyl-2H-tetrazolium bromide; PBS, phosphate-buffered saline.

Key words: adenosine, inosine, cytoprotection, liver, ischemiareperfusion, hepatocytes results suggest that the cytoprotective effects are related to intracellular actions, and, in the case of adenosine also involve intracellular conversion to inosine. The likely interpretation of these findings is that inosine serves as an alternative source of energy to produce ATP during hypoxic conditions. The protective effects are also partially dependent on adenosine kinase, as the inhibitor 4-amino-5-(3-bromophenyl)-7(6-morpholino-pyridin-3-yl)pyrido[2,3-d]pyrimidine, $2 \mathrm{HCl}$ (ABT 702, $30 \mu \mathrm{M}$ ) significantly reversed the protective effect of both adenosine and inosine during hypoxia and re-oxygenation. Collectively, the current results support the view that during hypoxia, adenosine and inosine exert cytoprotective effects via receptor-independent, intracellular modes of action, which, in part, depend on the restoration of cellular bioenergetics. The present study supports the view that testing of inosine for protection against various forms of warm and cold liver ischemia is relevant.

\section{Introduction}

Liver ischemia-reperfusion is a common problem in many clinical conditions such as liver transplantation, hepatic failure after shock, and liver surgery. Liver reperfusion injury not only causes liver dysfunction, but also frequently induces injury in extrahepatic organs, including the lung, the kidney and the heart $(1,2)$. Understanding the pathophysiological process of liver reperfusion injury is clinically and pathophysiologically important.

Ischemic preconditioning, which is defined as multiple cycles of brief ischemia and reperfusion before a prolonged ischemic insult, has been reported to exert protection in several organs, resulting in increased tolerance toward organ hypoxia. Ischemic preconditioning has been shown to attenuate the tissue injury observed after reperfusion of the liver (3-5). Several mediators, including adenosine, have been shown to play a crucial role in the protective response of ischemic preconditioning (3-6).

In the present study, we focused on adenosine and its endogenous metabolic derivate, inosine, to observe their effects in an in vitro model of liver I-R injury. For a long time inosine was considered to be an inactive metabolite. However, several studies have shown that it has immunomodulatory, 
neuroprotective, cardioprotective and cytoprotective effects (7-10). These effects have been attributed to several independent mechanisms. First, inosine can bind to $\mathrm{A}_{2 \mathrm{~A}}$ adenosine receptors activating several receptor dependent intracellular signaling pathways $(11,12)$. Second, previous studies showed in kidney epithelial cells that inosine serves as an alternative substrate for ATP generation during hypoxia $(13,14)$. Third, inosine (but not adenosine) can inhibit the activation of poly(ADP-ribose) polymerase enzyme (PARP) preserving cells from a suicidal utilization of $\mathrm{NAD}^{+}$and ATP and, subsequently, cell death (15).

In this study, we evaluated the potential cytoprotective effects of adenosine and inosine in a cell-based model of liver I-R injury and pharmacologically characterized their mode of action.

\section{Materials and methods}

Materials. Adenosine, inosine, 8-cyclopentyl-1,3-dipropylxanthine (CDPX), 8-(3-chlorostyryl) caffeine (CSC), alloxazine, MRS 1523 and erythro-9-(2-hydroxy-3-nonyl) adenine hydrochloride (EHNA) were obtained from Sigma-Aldrich (St. Louis, MO, USA). 4-amino-5-(3-bromophenyl)-7-(6-morpholinopyridin-3-yl)pyrido[2,3-d]pyrimidine, $2 \mathrm{HCl}$ (ABT 702) was purchased from Calbiochem-Merck, Darmstadt, Germany. The receptor antagonists and ABT 702 were dissolved in dimethylsulfoxide (DMSO): dilutions were made in phosphate-buffered saline (PBS, pH 7.4) to obtain a final 0.5\% DMSO content in the assay volume. EHNA was dissolved in distilled water. Adenosine and inosine were dissolved in DMEM.

Cell culture. The human hepatocellular carcinoma-derived cell line HepG2 was obtained from the European Collection of Cell Cultures (Salisbury, UK) and maintained in Dulbecco's modified Eagle's medium (DMEM) supplemented with $4.5 \mathrm{~g} / 1$ glucose and 10\% fetal bovine serum (Invitrogen, Carlsbad, CA, USA), $4 \mathrm{mM}$ glutamine, $100 \mathrm{IU} / \mathrm{ml}$ penicillin and $100 \mu \mathrm{g} / \mathrm{ml}$ streptomycin. Five days prior to the assay 10,000 cells/well were plated into 96-well tissue culture plates and cultured at $37^{\circ} \mathrm{C}$ in a $5 \% \mathrm{CO}_{2}$ atmosphere. Cells from passage numbers 9-25 were used for subsequent assays.

In vitro liver ischemia-reperfusion model. We developed a cell-based assay of liver ischemia-reperfusion in HepG2 human liver epithelial cells. HepG2 cells were plated into 96-well tissue culture plates. Cells were cultured for 5 days to form a confluent monolayer for the following assay. Culture medium was replaced with DMEM containing no glucose (Biochrom AG, Berlin, Germany) prior to induction of hypoxia. Culture plates were placed in gas-tight incubation chambers (Billups-Rothenberg Inc., Del Mar, CA, USA) and the chamber atmosphere was replaced by flushing the chamber with $95 \% \mathrm{~N}_{2}: 5 \% \mathrm{CO}_{2}$ mixture at $25 \mathrm{l} / \mathrm{min}$ flow rate for $5 \mathrm{~min}$. The hypoxic chamber was sealed and incubated at $37^{\circ} \mathrm{C}$ for various time periods. Following hypoxia, the culture medium was removed and fresh DMEM containing $4.5 \mathrm{~g} / \mathrm{l}$ glucose supplemented with $10 \%$ serum was added and the cells underwent re-oxygenation at $37^{\circ} \mathrm{C}$ in a $5 \% \mathrm{CO}_{2}$ atmosphere for various time periods depending on the specific experimental protocol. Cells exposed to hypoxia in complete culture medium served as controls (CTL), as no reduction was detected in cell viability compared to cells maintained in normal culture conditions (complete culture medium, $5 \% \mathrm{CO}_{2}$ atmosphere, $37^{\circ} \mathrm{C}$ ), if HepG2 cells were exposed to oxygen depletion with culture medium containing $4.5 \mathrm{~g} / \mathrm{l}$ glucose and $10 \%$ serum for $24 \mathrm{~h}$.

Inosine and adenosine proved to be markedly cytoprotective in our in vitro cell-based assay of liver I-R injury. In various studies we tested different periods of hypoxia (0-14-24 h) and subsequent re-oxygenation (0-4-24 h) in HepG2 cultures. Four groups were studied ( $\mathrm{n}=24$ for each group). The first group received pretreatment with adenosine, while the second group was pretreated with inosine prior to combined oxygen-glucose deprivation (COGD) conditions (from 300-1,000 $\mu \mathrm{M}$, applied $10 \mathrm{~min}$ before hypoxia). The third group (control) was subjected to COGD with drug vehicle only. The fourth group was the negative control group of the assay in which the cells were cultured in glucose containing medium ( $4.5 \mathrm{~g} / \mathrm{l})$ during the entire assay period. At the end of the experiments 3-(4,5-dimethyl2-thiazolyl)-2,5-diphenyl-2H-tetrazolium bromide (MTT) viability and lactate dehydrogenase (LDH) cytotoxicity assays were conducted as described below.

Pharmacological characterization of the cytoprotective effects of adenosine and inosine in the in vitro model of liver I-R. The concentration-dependence of the cytoprotective effects was tested in HepG2 cells subjected to COGD with adenosine or inosine pretreatment $(1,3,10,30,100,300,1,000-3,000 \mu \mathrm{M}$, $\mathrm{n}=3$ each). The effects of adenosine and inosine were compared on the same 96-well tissue culture plate. $A_{1}$ adenosine receptor antagonist CDPX $(16,17)$, selective $\mathrm{A}_{2 \mathrm{~A}}$ antagonist CSC $(18,19)$, the selective $A_{2 B}$ adenosine receptor antagonist alloxazine (20), and the $\mathrm{A}_{3}$ adenosine receptor antagonist MRS $1523(21,22)$ were added $30 \mathrm{~min}$ prior to adenosine or inosine $(300 \mu \mathrm{M})$ in the indicated concentration prior to COGD. The cytotoxicity of receptor antagonists was also tested under normoxic conditions.

The adenosine deaminase inhibitor EHNA (23) and the adenosine kinase inhibitor ABT $702(24,25)$ were applied at 10 and $30 \mu \mathrm{M}$ prior to administering adenosine or inosine and COGD. The combined administration of EHNA and ABT 702 was also investigated. In all analyses, all relevant assay conditions (including adenosine receptor antagonists assays, adenosine and inosine comparisons) were represented on the same 96-well tissue culture plate to prevent inter-plate assay variability. The experiments were repeated independently at least three times.

MTT cell viability assay. To estimate the number of viable cells, MTT was added to the cells at a final concentration of $0.5 \mathrm{mg} / \mathrm{ml}$ and cultured at $37^{\circ} \mathrm{C}$ in a $5 \% \mathrm{CO}_{2}$ atmosphere for $1 \mathrm{~h} \mathrm{(26).} \mathrm{The}$ incubation medium was removed and the converted formazan dye was dissolved in isopropanol and measured at $570 \mathrm{~nm}$ with background measurement at $690 \mathrm{~nm}$ on a PowerWave reader (BioTek Instruments,. Inc., Winooski, VT, USA). A calibration curve was created by measuring the converting capacity of MTT of serial dilutions of HepG2 cells. The viable cell count was calculated using Gen5 data reduction software.

LDH cytotoxicity assay. Cell culture supernatant $(30 \mu \mathrm{l})$ was mixed with $100 \mu$ l freshly prepared LDH assay reagent to reach 


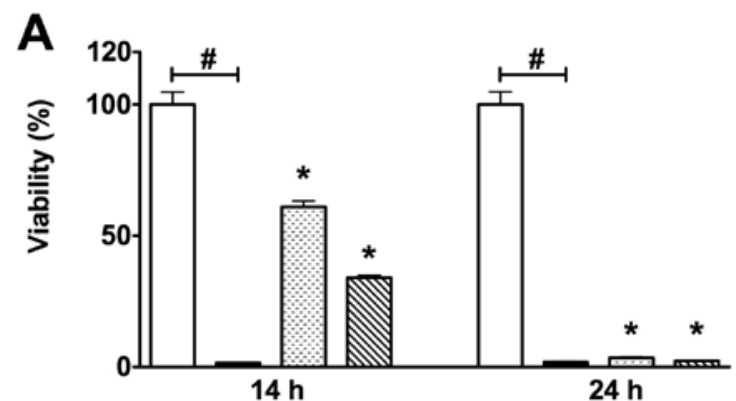

B

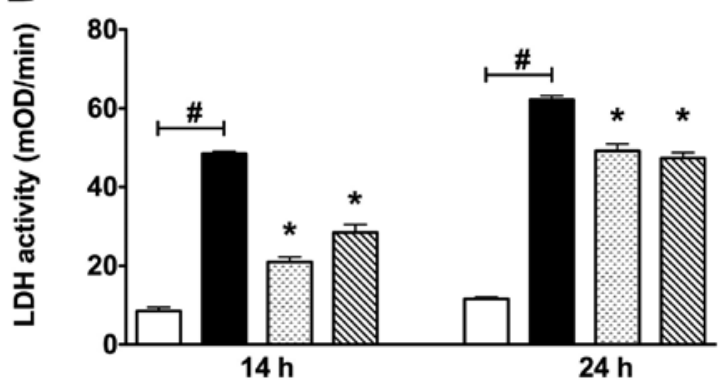

Figure 1. Viability and LDH activity are shown in HepG2 cultures during different periods of combined oxygen-glucose deprivation (COGD) and following a 4 h-long re-oxygenation. (A) Percent viability values by MTT assay and (B) LDH activities in $\mathrm{mOD} / \mathrm{min}$ are shown. Each group, except the control (CTL) group, was incubated in glucose-free medium under anaerobic conditions for 14- or 24-h periods and a subsequent $4 \mathrm{~h}$-long re-oxygenation phase by normalizing glucose and oxygen levels in the cell culture medium and atmosphere. Data are shown as the means \pm SEM ( $n=24$ for each group). White bar is control (CTL) group, black bar is COGD group during COGD without any pharmacological pretreatment, dotted bar shows $300 \mu \mathrm{M}$ adenosine (ADE) pretreatment group and ruled bar represents $300 \mu \mathrm{M}$ inosine (INO) pretreatment group. ADE and INO groups were also under COGD conditions. ${ }^{\#} \mathrm{P}<0.05$ compared to the $\mathrm{CTL}$ group and ${ }^{*} \mathrm{P}<0.05$ compared to the COGD group.

final concentrations of $85 \mathrm{mM}$ lactic acid, $1040 \mathrm{mM}$ nicotinamide adenine dinucleotide, $224 \mathrm{mM} \mathrm{N}$-methylphenazonium methyl sulfate, $528 \mathrm{mM}$ 2-(4-iodophenyl)-3-(4-nitrophenyl)5-phenyl-2H-tetrazolium chloride and $200 \mathrm{mM}$ Tris (pH 8.2). The changes in absorbance were read kinetically at $492 \mathrm{~nm}$ for $15 \mathrm{~min}$. LDH activity values are shown as $\mathrm{Vmax}$ in $\mathrm{mOD} / \mathrm{min}$ for kinetic assay (27).

Statistical analysis. Data are shown as the means \pm SEM. One-way ANOVA was used to detect differences between groups. Post hoc comparisons were made using Tukey's test. A value of $\mathrm{P}<0.05$ was considered to indicate statistically significant differences. All statistical calculations were performed using GraphPad Prism 5 analysis software.

\section{Results}

Characterization of an in vitro liver ischemia-reperfusion model in HepG2 cells. To develop a reproducible in vitro liver ischemia reperfusion model on HepG2 liver epithelial cells, we tested different periods (12, 14 and $24 \mathrm{~h})$ of COGD, followed by a subsequent re-oxygenation period of $4 \mathrm{~h}$ (Fig. 1). Twelve hours of hypoxia combined with $4 \mathrm{~h}$ of re-oxygenation did not induce a significant decline of the cell viability (data not shown). However, $14 \mathrm{~h}$ of hypoxia combined
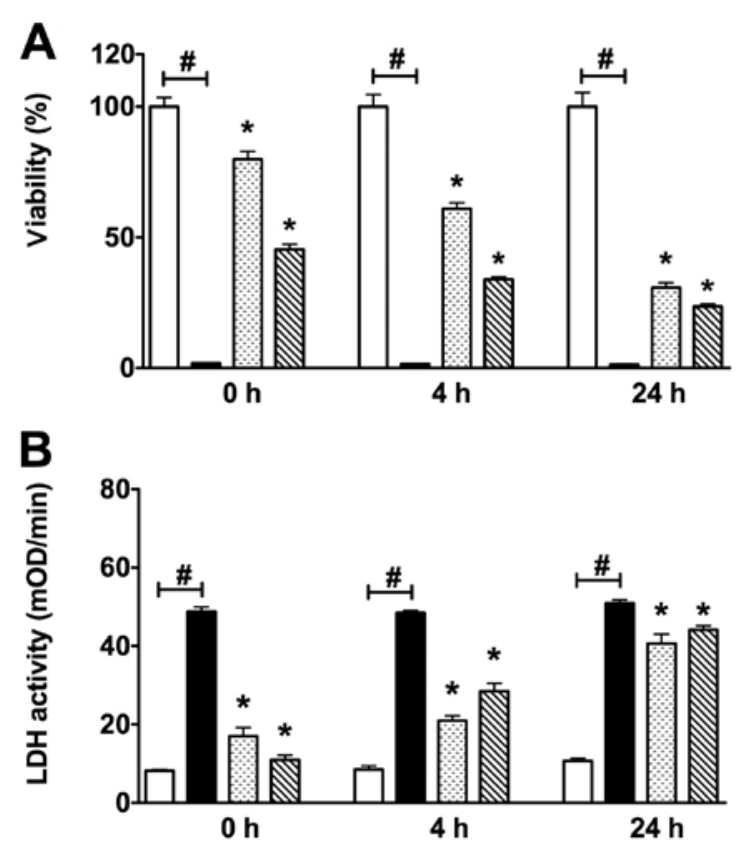

Figure 2. Viability and LDH activity are shown in HepG2 cultures during a 14 h-long combined oxygen-glucose deprivation (COGD) and following 0-4-24 h of re-oxygenation. (A) Percent viability values by MTT and (B) $\mathrm{LDH}$ activities in $\mathrm{mOD} / \mathrm{min}$ are shown. Each group, except the control (CTL) group, was incubated in glucose-free medium under anaerobic conditions for a $14 \mathrm{~h}$-long period and following a 0-4-24 h-long re-oxygenation phase by normalizing glucose and oxygen levels in the cell culture medium and atmosphere. Data are shown as the means \pm SEM ( $n=24$ for each group). White bar is control (CTL) group, black bar is COGD group during COGD without any pharmacological pretreatment, dotted bar shows $300 \mu \mathrm{M}$ adenosine (ADE) pretreatment group and ruled bar represents inosine pretreatment group at $300 \mu \mathrm{M}$ (INO). ADE and INO groups were also under COGD conditions. ${ }^{\#} \mathrm{P}<0.05$ compared to the CTL group and ${ }^{*} \mathrm{P}<0.05 \mathrm{com}-$ pared to the COGD group.

with $4 \mathrm{~h}$ re-oxygenation induced a significant decline of the cell viability. Furthermore, $24 \mathrm{~h}$ of hypoxia followed by a $4 \mathrm{~h}$ re-oxygenation period markedly reduced cellular viability in all groups, as detected by MTT viability assay. Both 14 and $24 \mathrm{~h}$ of COGD were associated with a significant elevation of LDH activity detected in the cell culture supernatant (Fig. 1).

Various re-oxygenation periods (0-4-24 h) were also investigated after $14 \mathrm{~h}$-long COGD. Increased cell injury was detected through the progression of the re-oxygenation period, as measured by both MTT and LDH assays (Fig. 2). Overall, these data indicate that in the current assay a substantial degree of cell injury occurs during the hypoxic period.

Effects of adenosine and inosine in an in vitro model of liver ischemia-reperfusion. Adenosine and inosine significantly protected against the loss of cell viability of HepG2 cultures during 14 and $24 \mathrm{~h}$ of the COGD group, and reduced LDH release from the cells (Fig. 3). Although adenosine and inosine significantly protected HepG2 cultures from 14 h hypoxia injury, during the progression of the re-oxygenation phase a progressive reduction in cell viability and enhanced LDH enzyme release were detected in all groups, as assessed by the MTT and LDH assays. These findings are consistent with the hypothesis that an extended hypoxia results in further cell damage during the reoxygenation (reperfusion) phase. Thus 
A

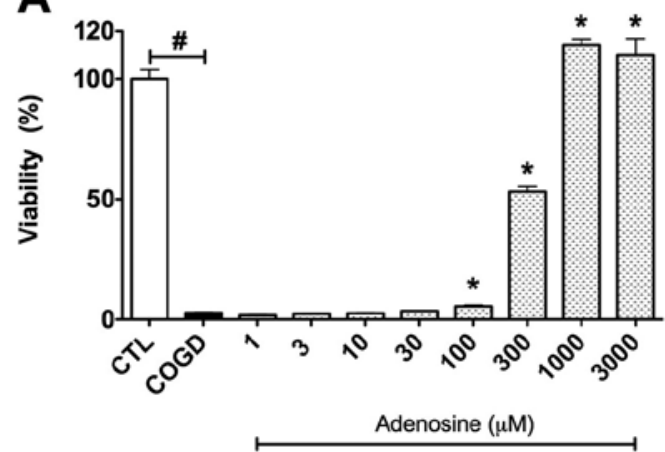

B

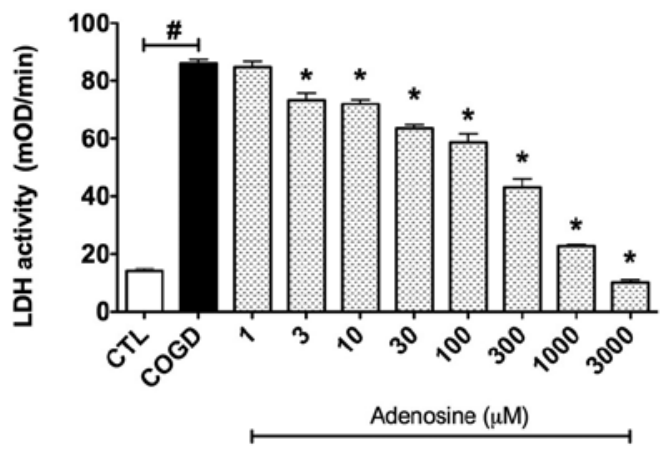

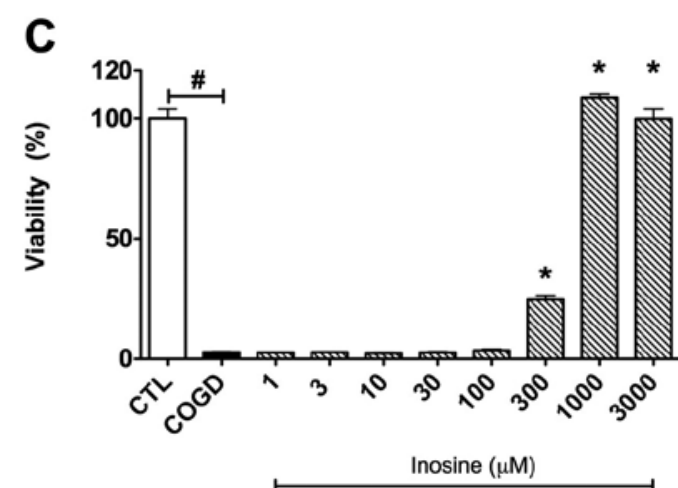

D

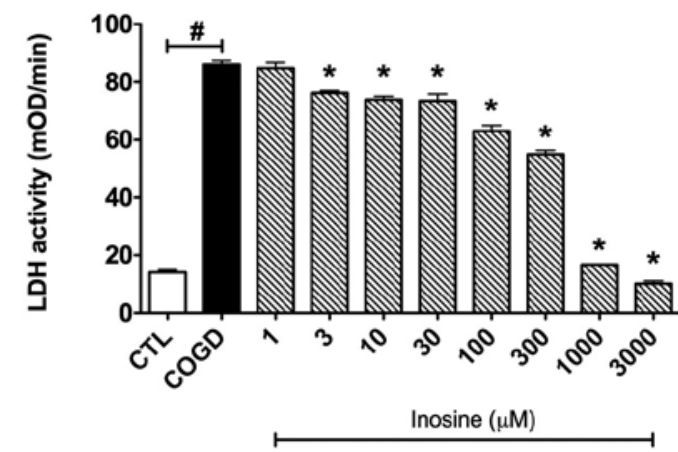

Figure 3. Dose-response effects of (A and B) adenosine and (C and D) inosine on percent viability values by MTT assay and LDH activities in mOD/min in HepG2 cultures exposed to a 14 h-long combined oxygen-glucose deprivation (COGD) and a subsequent 4 h-long re-oxygenation. Each group, except the control (CTL) group, was incubated in glucose-free medium under anaerobic conditions for a 14 h-long period and following a 4 h-long re-oxygenation phase by normalized glucose and oxygen levels in the cell culture medium and atmosphere. Data are shown as the means \pm SEM. White bar is control (CTL, $\mathrm{n}=16)$ group in the control conditions of the assay, black bar is COGD group $(n=32)$ during COGD without any pharmacological pretreatment, dotted bar shows the adenosine pretreatment group at 1,3,10,30,100,300,1,000 and 3,000 $\mu \mathrm{M}$ (ADE) and ruled bar represents the inosine pretreatment group at 1,3, 10,30, 100, $300,1,000$ and $3,000 \mu \mathrm{M}$ (INO). ADE and INO groups (n=3) were also under COGD conditions. ${ }^{\#} \mathrm{P}<0.05$ compared to the CTL group and ${ }^{*} \mathrm{P}<0.05$ compared to the COGD group.

our in vitro model clearly demonstrates the main aspects of the in vivo liver ischemia-reperfusion injury, with subsequent secondary injury occurring in the reperfusion phase.

Pharmacological characterization of the effects of adenosine and inosine in an in vitro liver ischemia-reperfusion model. For subsequent in-depth characterization of the effects of adenosine and inosine, we selected $14 \mathrm{~h}$ of hypoxia and $4 \mathrm{~h}$ of re-oxygenation periods as the standard assay conditions. First, we established a dose-response comparison between the cytoprotective effects of adenosine and inosine, by testing each compound in a concentration range of $1 \mu \mathrm{M}-3 \mathrm{mM}$. Adenosine and inosine showed cytoprotective effects already at $300 \mu \mathrm{M}$, and reached their maximum cytoprotective effect at $1,000 \mu \mathrm{M}$ (Fig. 3). Adenosine and inosine partially attenuated cellular LDH release, starting already at the concentration of $3 \mu \mathrm{M}$ (Fig. 3).

We next evaluated the potential involvement of adenosine receptors in the protective effects of adenosine and inosine. Cells were pretreated with the adenosine receptor antagonists CDPX, CSC, alloxazine, and MRS 1523 prior to administration of cytoprotective concentrations $(300 \mu \mathrm{M})$ of adenosine or inosine. None of the adenosine receptor antagonists affected the cytoprotective effects of adenosine and inosine during COGD and following a $4 \mathrm{~h}$-long re-oxygenation period (Fig. 4). These data suggest that adenosine and inosine exert their cytoprotective effects by receptor-independent pathways.

The adenosine deaminase inhibitor EHNA $(10 \mu \mathrm{M})$ almost fully reversed the protective effect of 300-1,000 $\mu \mathrm{M}$ adenosine during COGD and following a $4 \mathrm{~h}$-long re-oxygenation period (Fig. 5). On the other hand, EHNA did not influence the cytoprotective effect of inosine in same assay conditions (Fig. 5). The adenosine kinase inhibitor ABT $702(30 \mu \mathrm{M})$ significantly reversed the protective effect of 300 and $1,000 \mu \mathrm{M}$ adenosine and inosine during COGD and following a $4 \mathrm{~h}-$ long re-oxygenation period. We also tested both enzyme inhibitors in combined administration (Fig. 7). Notably, ABT 702, on its own, appeared to have a mild cytoprotective effect in our assay (Figs. 6 and 7).

\section{Discussion}

The present study utilizes a cell-based model of liver ischemia-reperfusion injury in cultured HepG2 cells subjected to combined oxygen-glucose deprivation followed by re-oxygenation. Experimental conditions similar to the current ones have previously been used in multiple studies in cultured hepatocytes and Kupffer cells to mimic conditions of ischemia, in order to 
A
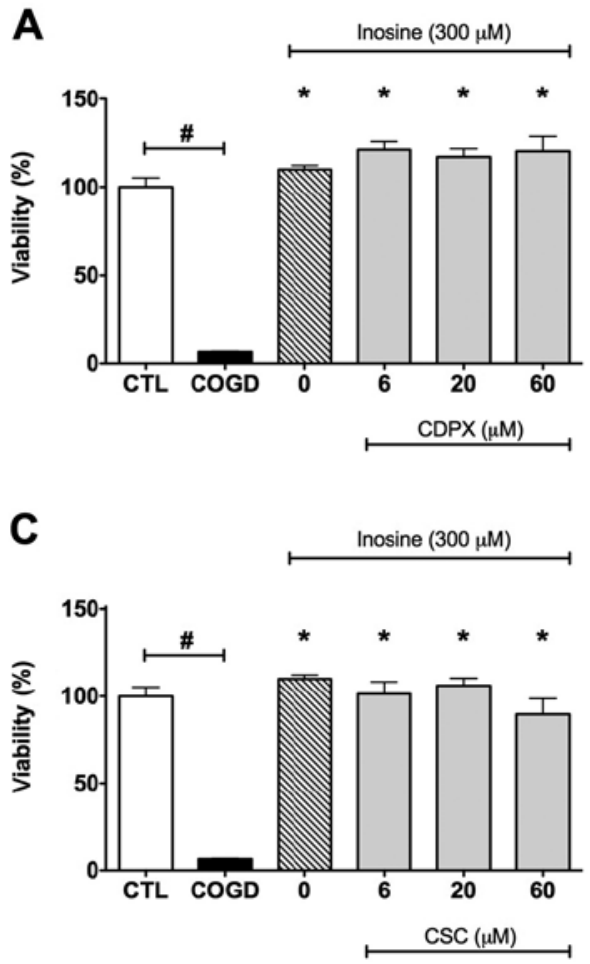

E
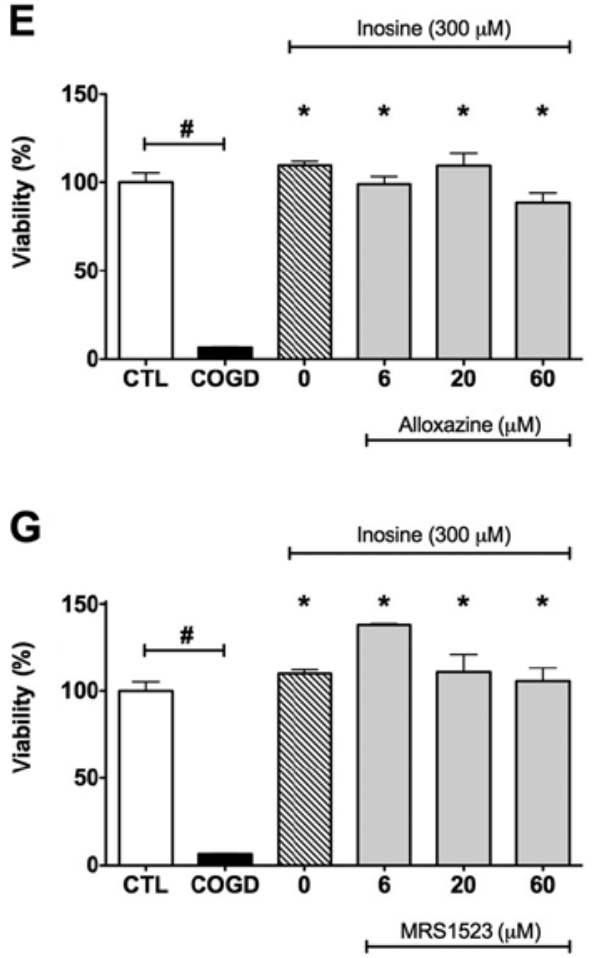

B

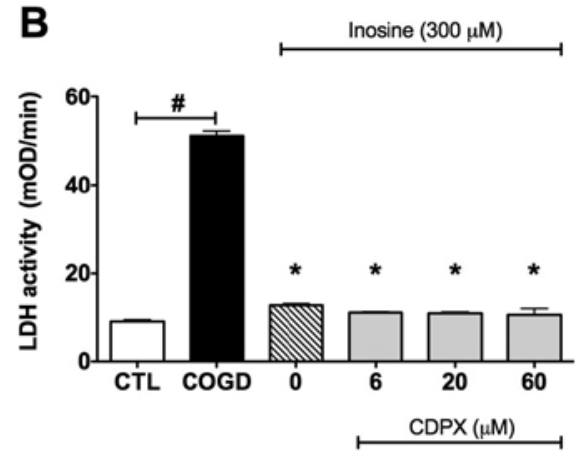

D
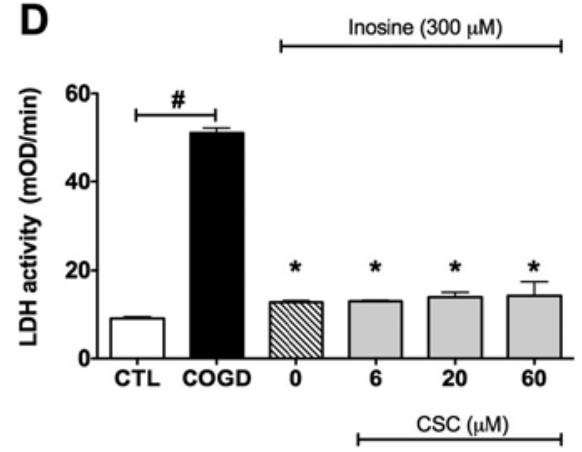

$\mathbf{F}$

Inosine $(300 \mu \mathrm{M})$

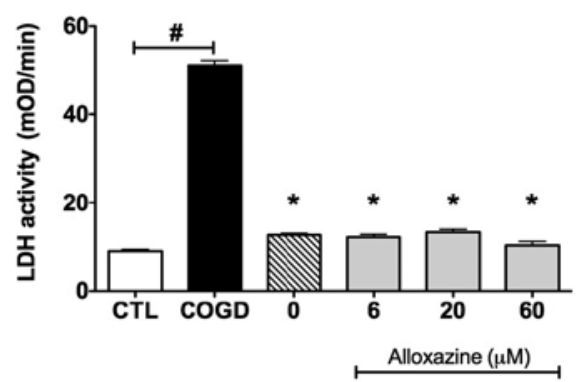

H

Inosine $(300 \mu \mathrm{M})$

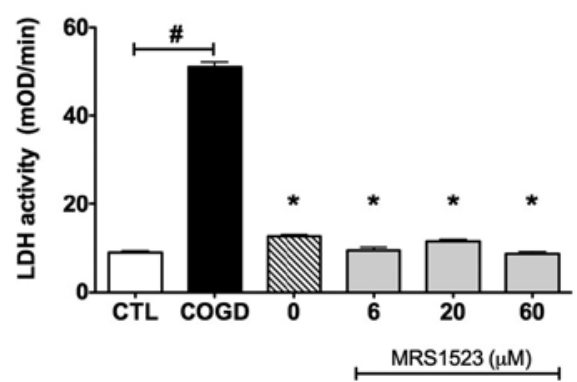

Figure 4. Effect of adenosine receptor antagonists on the cytoprotective effects of inosine. Confluent HepG2 cultures were subjected to combined oxygen-glucose deprivation (COGD, $\mathrm{n}=32$ ) for $14 \mathrm{~h}$ followed by a 4-h-long re-oxygenation period. (A and $\mathrm{B}$ ) The $\mathrm{A}_{1}$ adenosine receptor antagonist, CDPX, (C and D) the $\mathrm{A}_{2 \mathrm{~A}}$ adenosine receptor antagonist, $C S C$, $(E$ and $F)$ the $A_{2 B}$ adenosine receptor antagonist, alloxazine, and the $A_{3}$ adenosine receptor antagonist, $(\mathrm{G}$ and $\mathrm{H}) \mathrm{MRS} 1523$ were applied in the indicated concentrations $(\mathrm{n}=3) 30$ min prior to the inosine or adenosine pretreatment (INO or ADE, $\mathrm{n}=12$ ) and were present throughout the COGD period. Viability was measured by the MTT assay (A, C, E and G) and LDH activities (B, D, F and H) were measured from the cell culture supernatant. Controls (CTL, $\mathrm{n}=16)$ were exposed to hypoxia in complete culture medium. Data are shown as the means \pm SEM. ${ }^{\text {}} \mathrm{P}<0.05$ compared to CTL and ${ }^{*} \mathrm{P}<0.05$ compared to COGD. None of the adenosine receptor antagonists affected the cytoprotective effects of adenosine (data not shown) and inosine during COGD.

study pathways of cell death, signal transduction, free radical and oxidant production and inflammatory responses (28-33). Our results demonstrate that both adenosine and inosine exert cytoprotective effects in the current model, in a concentra- tion-dependent manner (when assessed by measurement of LDH release and mitochondrial activity by the MTT assay). Although in several experimental models the cytoprotective effects of adenosine and inosine are known to be dependent 

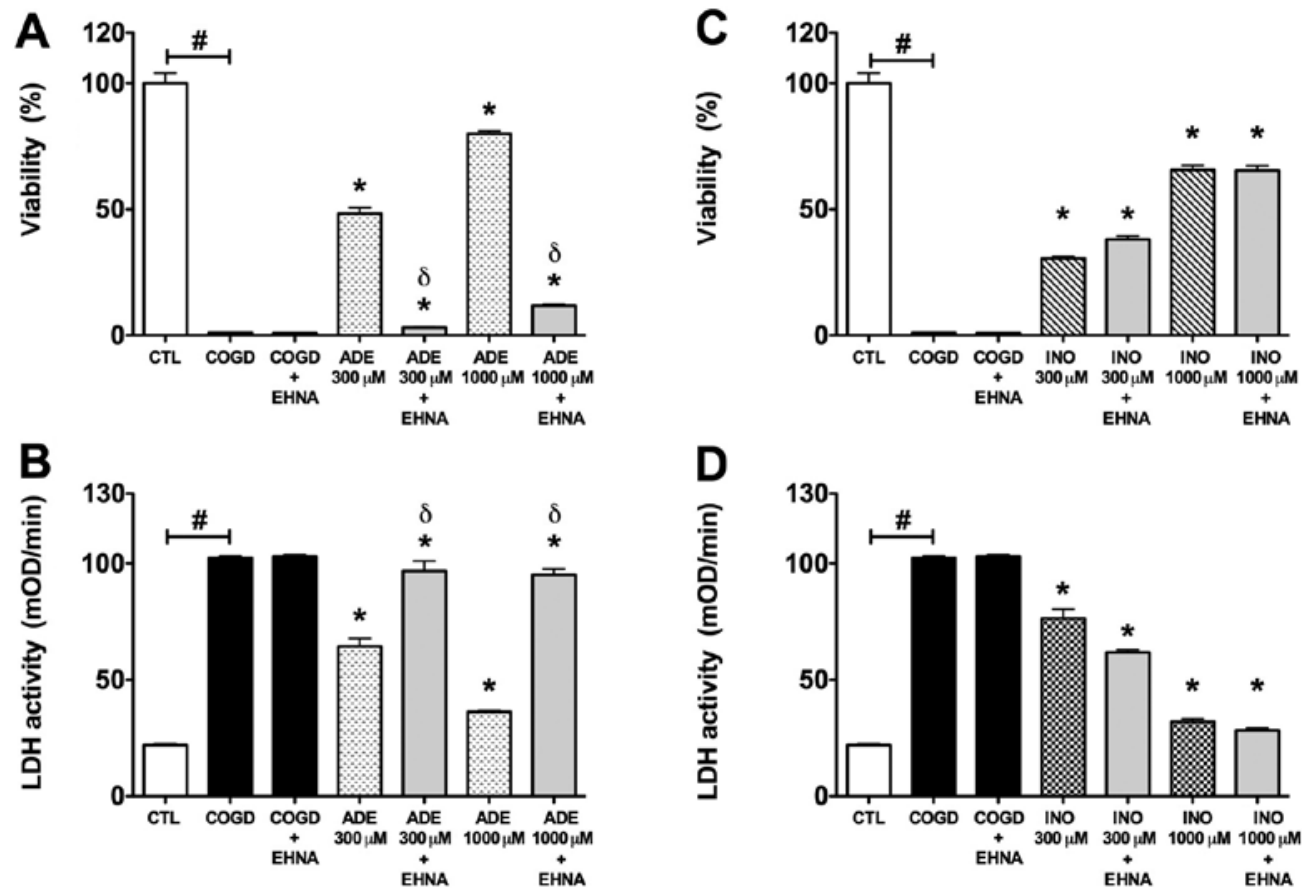

Figure 5. Effect of adenosine deaminase inhibitor (EHNA) on the cytoprotective action of 300-1,000 $\mu \mathrm{M}$ adenosine (ADE) and inosine (INO) in HepG2 cultures exposed to a $14 \mathrm{~h}$-long hypoxia period and a subsequent $4 \mathrm{~h}$ re-oxygenation. Data are shown as the means \pm SEM. (A and C) Percent viability values by MTT assay and (B and D) LDH activities in $\mathrm{mOD} / \mathrm{min}$ are shown. Seven groups were studied both of the adenosine and inosine. The COGD group during COGD (black bar, $\mathrm{n}=16$ ), a COGD group plus $10 \mu \mathrm{M}$ EHNA during COGD (black bar, $\mathrm{n}=16$ ), groups pre-treated with 300 or 1,000 $\mu \mathrm{M}$ adenosine (ADE) and inosine (INO) during COGD (ADE, dotted bar; INO, ruled bar, n=3) and finally groups pre-treated with 300 or 1,000 $\mu \mathrm{M}$ adenosine and inosine plus $10 \mu \mathrm{M}$ EHNA during COGD (ADE 300-1,000 $\mu \mathrm{M}+$ EHNA and INO 300-1,000 $\mu \mathrm{M}+$ EHNA are grey bar, $\mathrm{n}=3$ ). The white bar is the control (CTL, $\mathrm{n}=16$ ) group and represents the negative control of the assay. ${ }^{\#} \mathrm{P}<0.05$ compared to $\mathrm{CTL}$; ${ }^{*} \mathrm{P}<0.05$ compared to the COGD group; and ${ }^{\circ} \mathrm{P}<0.05$ compared to the $300-1,000 \mu \mathrm{M}$ ADE groups.
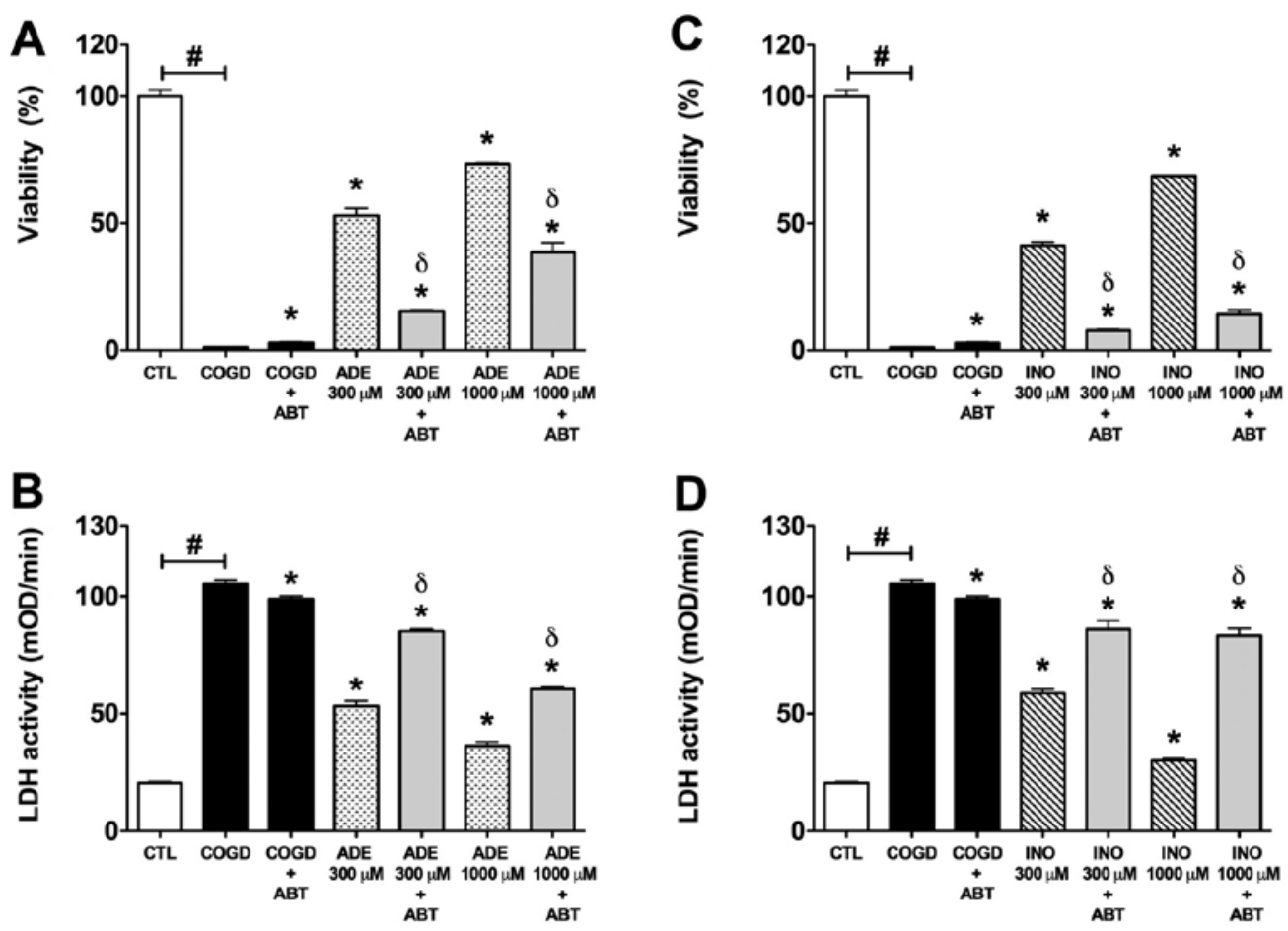

Figure 6. Effect of adenosine kinase inhibitor (ABT 702) on the cytoprotective action of 300-1,000 $\mu \mathrm{M}$ adenosine (ADE) and inosine (INO) in HepG2 cultures exposed to a $14 \mathrm{~h}$-long hypoxia period and a subsequent $4 \mathrm{~h}$ re-oxygenation. Data are shown as the means \pm SEM. (A and C) Percent viability values by MTT assay and (B and D) LDH activities in $\mathrm{mOD} / \mathrm{min}$ are shown. Seven groups were studied both of the adenosine and inosine. The COGD group during COGD (black bar, $\mathrm{n}=16$ ), a COGD group plus $30 \mu \mathrm{M} \mathrm{ABT} 702$ during COGD (black bar, $\mathrm{n}=16$ ), groups pre-treated with 300 or 1,000 $\mu \mathrm{M}$ adenosine (ADE) and inosine (INO) during COGD (ADE, dotted bar; INO, ruled bar, $\mathrm{n}=3$ ) and finally groups pre-treated with 300 or $1,000 \mu \mathrm{M}$ adenosine and inosine plus $30 \mu \mathrm{M}$ ABT 702 during COGD (ADE 300-1,000 $\mu \mathrm{M}+\mathrm{ABT}$ and INO 300-1,000 $\mu \mathrm{M}+\mathrm{ABT}$ are grey bars, $\mathrm{n}=3$ ). The white bar is the control (CTL, $\mathrm{n}=16$ ) group and represents the negative control of the assay. ${ }^{\#} \mathrm{P}<0.05$ compared to CTL; " $\mathrm{P}<0.05$ compared to the COGD group; and ${ }^{\circ} \mathrm{P}<0.05$ compared to the $300-1,000 \mu \mathrm{M}$ $\mathrm{ADE}$ and INO groups. 

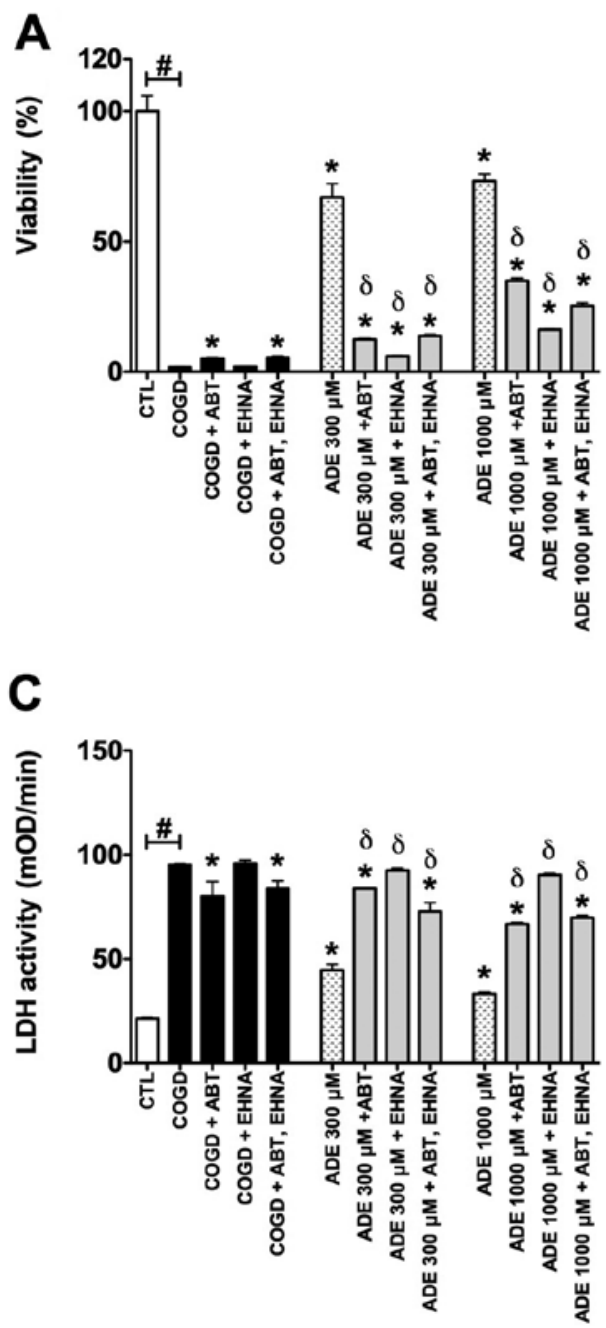

B

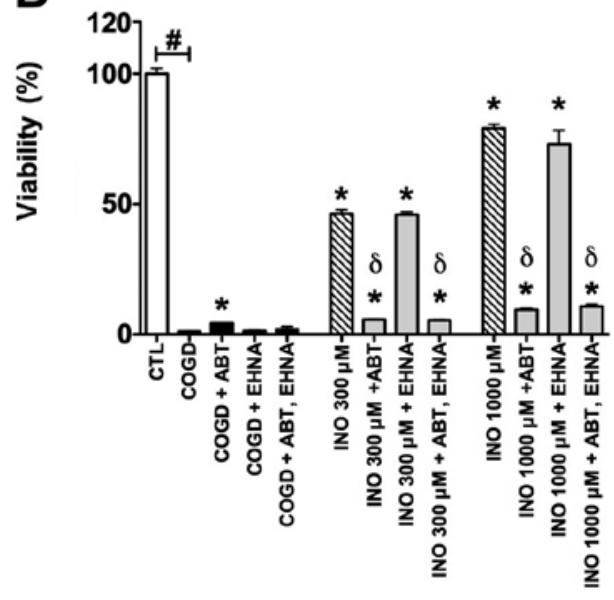

D

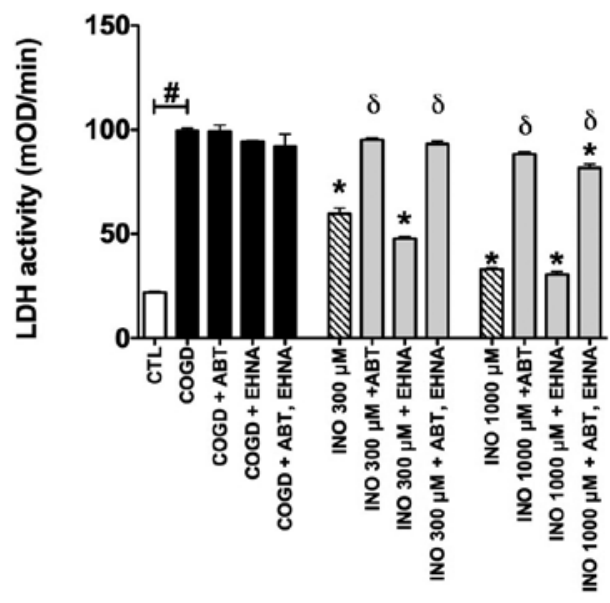

Figure 7. Collective effect of adenosine deaminase inhibitor (EHNA) and adenosine kinase inhibitor (ABT 702) on the cytoprotective actions of 300-1,000 $\mu \mathrm{M}$ adenosine (ADE) and inosine (INO) in HepG2 cultures exposed to a $14 \mathrm{~h}$-long hypoxia period and a subsequent $4 \mathrm{~h}$ re-oxygenation. Data are shown as the means \pm SEM. (A and C) Percent viability values by MTT assay and (B and D) LDH activities in $\mathrm{mOD} / \mathrm{min}$ are shown. Seven groups were studied both of the adenosine and inosine. The COGD group during COGD (black bar, n=32), a COGD group plus $30 \mu \mathrm{M}$ ABT 702 during COGD (black bar, $\mathrm{n}=3$ ), a COGD group plus $10 \mu \mathrm{M}$ EHNA during COGD (black bar, $\mathrm{n}=3$ ), a COGD group plus $30 \mu \mathrm{M}$ ABT 702 and $10 \mu \mathrm{M}$ EHNA in combination during COGD (black bar, $\mathrm{n}=3$ ), groups pre-treated with 300-1,000 $\mu \mathrm{M}$ adenosine (ADE) and inosine (INO) during COGD (ADE, dotted bar; INO, ruled bar, n=3) and finally groups pre-treated with 300 or $1,000 \mu \mathrm{M}$ adenosine and inosine plus $30 \mu \mathrm{M}$ ABT 702 or $10 \mu \mathrm{M}$ EHNA during COGD (ADE/INO 300/1,000 $\mu \mathrm{M}+\mathrm{ABT} 702 / \mathrm{EHNA}$ or in combination are grey bars, $\mathrm{n}=3)$. The white bar is the control $(\mathrm{CTL}, \mathrm{n}=16)$ group and represents the negative control of the assay, subjected to hypoxia in complete culture medium. ${ }^{~} \mathrm{P}<0.05$ compared to CTL; ${ }^{P} \mathrm{P}<0.05$ compared to the COGD group; and ${ }^{\circ} \mathrm{P}<0.05$ compared to the $300-1,000 \mu \mathrm{M}$ ADE and INO groups.

on activation of adenosine $\mathrm{A}_{2 \mathrm{~A}}$ receptors $(11,12,34)$, the results of the current study demonstrate that the protective effect of adenosine and inosine in the current experimental conditions were not mediated by adenosine receptor-dependent pathways, as evidenced by the failure of specific adenosine receptor blockers to prevent the protective effects. Although several reports suggest a role for cell surface adenosine receptors in the reduction of liver reperfusion injury in vivo (35-39), it is likely that the location of these receptors is primarily on mononuclear cells involved in pro-inflammatory/immune responses (as opposed to hepatocytes).

While adenosine receptors failed to play a role in the cytoprotective effects of adenosine and inosine described in the present study, the data suggest the involvement of receptorindependent intracellular actions that are related to a direct regulation of cellular bioenergetics. We utilized the pharmacological inhibitor EHNA to inhibit adenosine deaminase, the enzyme that is responsible for the intracellular conversion of adenosine to inosine. EHNA significantly decreased the viability of the adenosine-treated cells subjected to COGD and also significantly increased the LDH release from the cells (Fig. 5). On the other hand, EHNA did not reduce the protective effect of inosine. These data are consistent with the hypothesis that, ultimately, an intracellular action, mediated by inosine, is responsible for the protective effect of adenosine. Our interpretation of the experimental findings is that, similar to astrocytes and kidney epithelial cells subjected to hypoxia and re-oxygenation $(13,14,23)$, the conversion of adenosine to inosine and its subsequent metabolism to ribose-phosphate, followed by ATP generation via the pentose phosphate pathway are responsible for the observed cytoprotective effects.

Haun et al (23), Jurkowitz et al (40) and Litsky et al (41) demonstrated that the ribose moiety of the adenosine and inosine can be used as a precursor for phosphorylated 

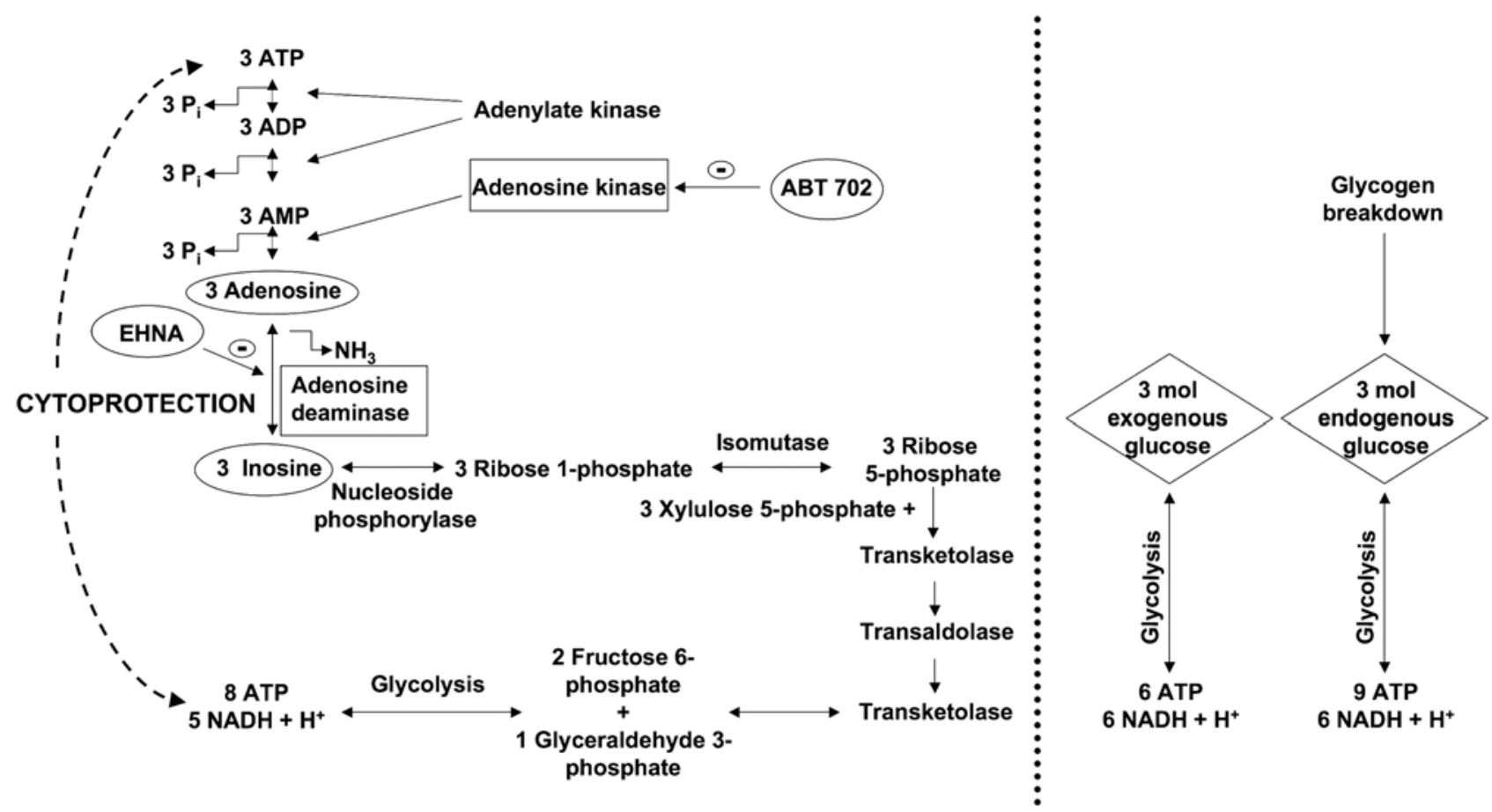

Figure 8. Scheme representing some of the proposed metabolic pathways for the conversion of adenosine and inosine into different substrates for the glycolytic pathway. The diagram also shows an alternative way to produce energy in the absence of glucose during hypoxic injury.

glycolytic intermediates in reactions catalyzed by enzymes of the pentose phosphate pathway. The first reaction in this pathway is the phosphorolysis of inosine and the formation of ribose 1-phosphate or hypoxanthine, which is catalyzed by purine nucleoside phosphorylase. Three ribose 1-phosphates are isomerized to three D-ribose 5-phosphates, which then convert to two fructose 6-phosphates and one glyceraldehyde 3-phosphate, via transaldolases and transketolases of the pentose phosphate pathway. These phosphorylated intermediates enter the glycolytic pathway yielding a net production of 8 moles ATP and 5 moles $\mathrm{NADH}+\mathrm{H}^{+}$from three molecules of ribose 1-phosphate (Fig. 8). All produced $\mathrm{NADH}+\mathrm{H}^{+}$convert to $\mathrm{NAD}^{+}$by lactate dehydrogenase $(\mathrm{LDH})$ in anaerobic conditions. However, after a while, lactate accumulates resulting in cellular acidosis. For abolishing the acidosis lactate degradation to pyruvate and its further decomposition in the Krebs cycle at the presence of oxygen is indispensable.

From the same molar amount ( 3 moles) of extracellular (or exogenous) glucose: 6 moles of ATP and 6 moles of $\mathrm{NADH}+\mathrm{H}^{+}$are produced during the glycolysis (Fig. 8). From the breakdown of glycogen, 3 moles of intracellular glucose-1 phosphate can produce a maximum of 9 moles of net ATP and 6 moles of $\mathrm{NADH}+\mathrm{H}^{+}$. On the other hand, from 3 moles of adenosine or inosine, the cell can produce net 8 moles of ATP and 5 moles of $\mathrm{NADH}+\mathrm{H}^{+}$. Thus, the cells tend to elevate the intracellular $\mathrm{NAD}+/ \mathrm{NADH}+\mathrm{H}^{+}$ratio, thereby regenerating as many $\mathrm{NADH}+\mathrm{H}^{+}$molecules as possible within a short time.

On the other hand, $\mathrm{NAD}^{+}$molecules are required to continue the glycolysis and lactate intermediates inhibit the further regeneration if the $\mathrm{NADH}+\mathrm{H}^{+}$molecules thereby impairing glycolysis. During excessive hypoxia, the accumulation of $\mathrm{NADH}+\mathrm{H}^{+}$occurs and, subsequently, inhibition of several enzymes (citrate synthase, isocitrate-dehydrogenase, $\alpha$-ketoglutarate dehydrogenase) occurs, thereby interfering with the Krebs cycle, which is controlled by the ratio of the NADH/NAD ${ }^{+}$and the ATP/ADP. Furthermore, during massive anaerobic conditions, $\mathrm{NADH}+\mathrm{H}^{+}$accumulation also leads to an inhibition of glycolysis. In summary, during COGD, adenosine and inosine may delay the accumulation of $\mathrm{NADH}+\mathrm{H}^{+}$and they can serve as a source of energy to maintain basal cellular function. In prolonged hypoxia, the accumulation of $\mathrm{NADH}+\mathrm{H}^{+}$is inevitable and the glycolysis and the Krebs cycle are both inhibited. Thus, long-term absence of the terminal oxidation and the regeneration of $\mathrm{NADH}+\mathrm{H}^{+}$ to $\mathrm{NAD}^{+}$result in severe cellular energy imbalance.

The results of the present study also demonstrated that the administration of the adenosine kinase inhibitor ABT 702 reversed all of the protective effects of adenosine and inosine. These findings are consistent with the hypothesis that adenosine kinase is responsible for producing AMP, ADP, and, eventually, ATP from adenosine. When sufficient ADP molecules are present in the cells, ATP can be created from ADP both via the adenosine kinase-mediated route and via the pentose phosphate pathway. The inhibition of the adenosine kinase pathway by ABT 702 results in less ADP production in the adenosine kinase-mediated pathway, which induces less ATP generation in the pentose phosphate shunt as well. This mechanism explains that, i) ATP production of the pentose phosphate pathway depends on the amount of ADP molecules derived from the adenosine kinase mediated route, and ii) provides evidence that administration of adenosine kinase inhibitor ABT 702 reversed all of the protective effects of adenosine and inosine. Furthermore, adenosine kinase inhibitor (ABT 702) administration without exogenous adenosine or inosine affords a mild cytoprotective effect, but prevents the cytoprotection provided by exogenous adenosine or inosine (Figs. 6 and 7). 
Our data and the above considerations, taken together, indicate that adenosine and inosine may exert some of their cytoprotective effects under our current experimental conditions by stepping in as an emergency energy source, when glucose is insufficient to support cellular functions. This hypothesis is supported both by several reports in the literature where cellular ATP levels were elevated in ischemic or hypoxic cells treated with adenosine or inosine $(23,40,42-44)$ as well as by our measurements $(13,14)$. Although we have not directly measured the transport of adenosine or inosine into the cells, previous studies have demonstrated that these purines can readily enter the cells $(23,40)$. We propose that the two processes, i) degradation of adenosine and inosine via the pentose-phosphate pathway, and ii) the phosphorylation of adenosine to AMP, are required in a well-balanced parallel fashion. Our hypothesis is that both pathways are necessary at the same time to support the generation of ATP under hypoxic conditions. The first process provides the energy, while the second one supplies the substrate (e.g. adenosine, AMP, ADP) to convert it into a high energy intermediate that conserves it in a ready-to-use form. Markedly, the combined blockage of adenosine deaminase (by EHNA) and adenosine kinase (by ABT 702) resulted in no further reduction in cell viability after COGD (as compared to either inhibitor), which supports that these enzymes take part in the same cytoprotective mechanism (Fig. 7).

In conclusion, it is likely that the cytoprotective effects of adenosine and inosine involve multiple, parallel and interrelated mechanisms under the current experimental conditions. During ischemia and inflammation, the concentration of purine metabolites increases dramatically in the extracellular space. ATP degrades into AMP and subsequently to adenosine, which may be released from the cells and appears in the extracellular space. Inosine can be formed from adenosine with an adenosine deaminase enzyme, which occurs both intra- and extracellularly. Consistent with these notions, there are several reports that demonstrate the cytoprotective effect of endogenously formed adenosine in the context of acute ischemic injury of the liver $(45,46)$.

The current study shows that adenosine and inosine are cytoprotective on HepG2 cultures exposed to combined oxygen-glucose deprivation. This protective effect is not mediated by a receptor-dependent pathway, but it is likely mediated by maintenance of cellular bioenergetics due to the utilization of adenosine and inosine as alternative substrates for ATP generation.

While the therapeutic utilization of adenosine as a hepatoprotective agent in vivo is difficult due to its short half-life and adverse cardiovascular side-effect profile, inosine may emerge as a potential candidate. Indeed, several recent studies have demonstrated that administration of inosine can be protective against various forms of ischemic conditions (7-10). The current results may provide a mechanistic explanation to the previously reported protective effect of inosine in vitro as an adjuvant to organ storage solutions (47) or in vivo as a protective agent in a rat model of hepatic reperfusion injury (48) and can stimulate further studies to explore whether inosine has the potential to improve cellular bioenergetics and to protect hepatocytes in various forms of liver injury, including various forms of warm ischemia or cold ischemia associated with liver transplantation.

\section{Acknowledgements}

This study was supported by a grant from the National Institutes of Health and by the Oszkar Asboth project grant of the National Office for Research and Technology (Budapest, Hungary). The technical assistance of Ms. Nora Nagy is appreciated.

\section{References}

1. Carden DL and Granger DN: Pathophysiology of ischaemiareperfusion injury. J Pathol 190: 255-266, 2000.

2. Frangogiannis NG: Chemokines in ischemia and reperfusion. Thromb Haemost 97: 738-747, 2007.

3. Peralta C, Bartrons R, Riera L, Manzano A, Xaus C, Gelpi E and Rosello-Catafau J: Hepatic preconditioning preserves energy metabolism during sustained ischemia. Am J Physiol Gastrointest Liver Physiol 279: G163-G171, 2000.

4. Cavalieri B, Perrelli MG, Aragno M, Mastrocola R, Corvetti G, Durazzo M, Poli G and Cutrin JC: Ischemic preconditioning attenuates the oxidant-dependent mechanisms of reperfusion cell damage and death in rat liver. Liver Transpl 8: 990-999, 2002.

5. Lee WY and Lee SM: Ischemic preconditioning protects postischemic oxidative damage to mitochondria in rat liver. Shock 24: 370-375, 2005

6. Carini R and Albano E: Recent insights on the mechanisms of liver preconditioning. Gastroenterology 125: 1480-1491, 2003.

7. Hasko G, Sitkovsky MV and Szabo C: Immunomodulatory and neuroprotective effects of inosine. Trends Pharmacol Sci 25: 152-157, 2004.

8. Spitsin S, Hooper DC, Leist T, Streletz LJ, Mikheeva T and Koprowskil H: Inactivation of peroxynitrite in multiple sclerosis patients after oral administration of inosine may suggest possible approaches to therapy of the disease. Mult Scler 7: 313-319, 2001.

9. Szabo G, Stumpf N, Radovits T, Sonnenberg K, Gero D, Hagl S, Szabo C and Bahrle S: Effects of inosine on reperfusion injury after heart transplantation. Eur J Cardiothorac Surg 30: 96-102, 2006.

10. Veres G, Radovits T, Seres L, Horkay F, Karck M and Szabo G: Effects of inosine on reperfusion injury after cardiopulmonary bypass. J Cardiothorac Surg 5: 106, 2010.

11. Gomez G and Sitkovsky MV: Differential requirement for $A_{2 a}$ and $\mathrm{A}_{3}$ adenosine receptors for the protective effect of inosine in vivo. Blood 102: 4472-4478, 2003.

12. Rahimian R, Fakhfouri G, Daneshmand A, Mohammadi H, Bahremand A, Rasouli MR, Mousavizadeh K and Dehpour AR: Adenosine $\mathrm{A}_{2 \mathrm{~A}}$ receptors and uric acid mediate protective effects of inosine against TNBS-induced colitis in rats. Eur J Pharmacol 649: 376-381, 2010 .

13. Modis K, Gero D, Nagy N, Szoleczky P, Toth ZD and Szabo C: Cytoprotective effects of adenosine and inosine in an in vitro model of acute tubular necrosis. Br J Pharmacol 158: 1565-1578, 2009.

14. Szoleczky P, Modis K, Nagy N, Dori Toth Z, DeWitt D, Szabo C and Gero D: Identification of agents that reduce renal hypoxiare-oxygenation injury using cell-based screening: purine nucleosides are alternative energy sources in LLC-PK1 cells during hypoxia. Arch Biochem Biophys 517: 53-70, 2012.

15. Virag L and Szabo C: Purines inhibit poly(ADP-ribose) polymerase activation and modulate oxidant-induced cell death. FASEB J 15: 99-107, 2001.

16. Bruns RF, Fergus JH, Badger EW, Bristol JA, Santay LA, Hartman JD, Hays SJ and Huang CC: Binding of the $\mathrm{A}_{1}$-selective adenosine antagonist 8-cyclopentyl-1,3-dipropylxanthine to rat brain membranes. Naunyn Schmiedebergs Arch Pharmacol 335: 59-63, 1987.

17. Kim J, Kim M, Song JH and Lee HT: Endogenous $A_{1}$ adenosine receptors protect against hepatic ischemia reperfusion injury in mice. Liver Transpl 14: 845-854, 2008.

18. Lee HT and Emala CW: Systemic adenosine given after ischemia protects renal function via $\mathrm{A}(2 \mathrm{a})$ adenosine receptor activation. Am J Kidney Dis 38: 610-618, 2001.

19. Yasuda N, Inoue T, Horizoe T, Nagata K, Minami H, Kawata T, Hoshino Y, Harada H, Yoshikawa S, Asano O, Nagaoka J, Murakami M, Abe S, Kobayashi S and Tanaka I: Functional characterization of the adenosine receptor contributing to glycogenolysis and gluconeogenesis in rat hepatocytes. Eur J Pharmacol 459: 159-166, 2003. 
20. Rose'Meyer RB, Harrison GJ and Headrick JP: Enhanced adenosine $\mathrm{A}(2 \mathrm{~B})$ mediated coronary response in reserpinised rat heart. Naunyn Schmiedebergs Arch Pharmacol 367: 266-273, 2003.

21. Di Sole F, Cerull R, Babich V, Casavola V, Helmle-Roth C and Burckhardt G: Short- and long-term $\mathrm{A}_{3}$ adenosine receptor activation inhibits the $\mathrm{Na}^{+} / \mathrm{H}^{+}$exchanger NHE3 activity and expression in opossum kidney cells. J Cell Physiol 216: 221-233, 2008.

22. Ohana G, Bar-Yehuda S, Arich A, Madi L, Dreznick Z, RathWolfson L, Silberman D, Slosman G and Fishman P: Inhibition of primary colon carcinoma growth and liver metastasis by the $\mathrm{A}_{3}$ adenosine receptor agonist CF101. Br J Cancer 89: 1552-1558, 2003.

23. Haun SE, Segeleon JE, Trapp VL, Clotz MA and Horrocks LA: Inosine mediates the protective effect of adenosine in rat astrocyte cultures subjected to combined glucose-oxygen deprivation. J Neurochem 67: 2051-2059, 1996.

24. Jarvis MF, Yu H, Kohlhaas K, Alexander K, Lee CH, Jiang M, Bhagwat SS, Williams M and Kowaluk EA: ABT-702 (4-amino5-(3-bromophenyl)-7-(6-morpholinopyridin-3-yl)pyrido[2,3-d] pyrimidine), a novel orally effective adenosine kinase inhibitor with analgesic and anti-inflammatory properties: I. In vitro characterization and acute antinociceptive effects in the mouse. J Pharmacol Exp Ther 295: 1156-1164, 2000.

25. Kowaluk EA, Mikusa J, Wismer CT, Zhu CZ, Schweitzer E, Lynch JJ, Lee CH, Jiang M, Bhagwat SS, Gomtsyan A, McKie J, Cox BF, Polakowski J, Reinhart G, Williams M and Jarvis MF: ABT-702 (4-amino-5-(3-bromophenyl)-7-(6-morpholinopyridin- 3-yl)pyrido[2,3-d]pyrimidine), a novel orally effective adenosine kinase inhibitor with analgesic and anti-inflammatory properties. II. In vivo characterization in the rat. J Pharmacol Exp Ther 295: 1165-1174, 2000.

26. Jagtap P, Soriano FG, Virag L, Liaudet L, Mabley J, Szabo E, Hasko G, Marton A, Lorigados CB, Gallyas F Jr, Sumegi B Hoyt DG, Baloglu E, VanDuzer J, Salzman AL, Southan GJ and Szabo C: Novel phenanthridinone inhibitors of poly (adenosine 5'-diphosphate-ribose) synthetase: potent cytoprotective and antishock agents. Crit Care Med 30: 1071-1082, 2002.

27. Gero D, Modis K, Nagy N, Szoleczky P, Toth ZD, Dorman G and Szabo C: Oxidant-induced cardiomyocyte injury: Identification of the cytoprotective effect of a dopamine 1 receptor agonist using a cell-based high-throughput assay. Int J Mol Med 20: 749-761, 2007.

28. Ohsaka Y, Ohgiya S, Hoshino T and Ishizaki K: Phosphorylation of c-Jun N-terminal kinase in human hepatoblastoma cells is transiently increased by cold exposure and further enhanced by subsequent warm incubation of the cells. Cell Physiol Biochem 12: $111-118,2002$

29. Laurens M, Defamie V, Scozzari G, Schmid-Alliana A, Gugenheim J and Crenesse D: Hypoxia-re-oxygenation-induced chemokine transcription is not prevented by preconditioning or intermittent hypoxia, in mice hepatocytes. Transpl Int 18 444-452, 2005

30. Roudier E, Bachelet $\mathrm{C}$ and Perrin A: Pyruvate reduces DNA damage during hypoxia and after re-oxygenation in hepatocellular carcinoma cells. FEBS J 274: 5188-5198, 2007.

31. Bhogal RH, Curbishley SM, Weston CJ, Adams DH and Afford SC: Reactive oxygen species mediate human hepatocyte injury during hypoxia/re-oxygenation. Liver Transpl 16 1303-1313, 2010.

32. Kim JS, Wang JH and Lemasters JJ: Mitochondrial permeability transition in rat hepatocytes after anoxia/re-oxygenation: role of $\mathrm{Ca}^{2+}$-dependent mitochondrial formation of reactive oxygen species. Am J Physiol Gastrointest Liver Physiol 302: G723-G731, 2012.
33. Pillai VC, Snyder RO, Gumaste U, Thekkumkara TJ and Mehvar R: Effects of transient overexpression or knockdown of cytochrome $\mathrm{P} 450$ reductase on reactive oxygen species generation and hypoxia re-oxygenation injury in liver cells. Clin Exp Pharmacol Physiol 38: 846-853, 2011.

34. Szabo $C$ and Pacher P: The outsiders: emerging roles of ectonucleotidases in inflammation. Sci Transl Med 4: 146ps14, 2012

35. Gallos G, Ruyle TD, Emala CW and Lee HT: $A_{1}$ adenosine receptor knockout mice exhibit increased mortality, renal dysfunction, and hepatic injury in murine septic peritonitis. Am J Physiol Renal Physiol 289: F369-F376, 2005.

36. Day YJ, Marshall MA, Huang L, McDuffie MJ, Okusa MD and Linden J: Protection from ischemic liver injury by activation of $\mathrm{A}_{2 \mathrm{~A}}$ adenosine receptors during reperfusion: inhibition of chemokine induction. Am J Physiol Gastrointest Liver Physiol 286: G285-G293, 2004

37. Ben-Ari Z, Pappo O, Sulkes J, Cheporko Y, Vidne BA and Hochhauser E: Effect of adenosine $\mathrm{A}_{2 \mathrm{~A}}$ receptor agonist (CGS) on ischemia/reperfusion injury in isolated rat liver. Apoptosis 10 955-962, 2005

38. Lappas CM, Day YJ, Marshall MA, Engelhard VH and Linden J: Adenosine $\mathrm{A}_{2 \mathrm{~A}}$ receptor activation reduces hepatic ischemia reperfusion injury by inhibiting CD1d-dependent NKT cell activation. J Exp Med 203: 2639-2648, 2006.

39. León Fernández O, Pantoja M, Díaz Soto M, Dranguet J, García Insua M, Viebhan-Hánsler R, Menéndez Cepero $\mathrm{S}$ and Calunga Fernández J: Ozone oxidative preconditioning is mediated by $\mathrm{A}_{1}$ adenosine receptors in a rat model of liver ischemia/reperfusion. Transpl Int 21: 39-48, 2008

40. Jurkowitz MS, Litsky ML, Browning MJ and Hohl CM Adenosine, inosine, and guanosine protect glial cells during glucose deprivation and mitochondrial inhibition: correlation between protection and ATP preservation. J Neurochem 71: 535-548, 1998.

41. Litsky ML, Hohl CM, Lucas JH and Jurkowitz MS: Inosine and guanosine preserve neuronal and glial cell viability in mouse spinal cord cultures during chemical hypoxia. Brain Res 821 426-432, 1999.

42. Mandel LJ, Takano T, Soltoff SP and Murdaugh S: Mechanisms whereby exogenous adenine nucleotides improve rabbit renal proximal function during and after anoxia. J Clin Invest 81: 1255-1264, 1988 .

43. Takeo S, Tanonaka K, Miyake K and Imago M: Adenine nucleotide metabolites are beneficial for recovery of cardiac contractile force after hypoxia. J Mol Cell Cardiol 20: 187-199, 1988.

44. Weinberg JM and Humes HD: Increases of cell ATP produced by exogenous adenine nucleotides in isolated rabbit kidney tubules. Am J Physiol 250: F720-F733, 1986.

45. Ajamieh HH, Candelario-Jalil E, Fernandez OS and Gerbes AL: Ischaemic and pharmacological preconditionings protect liver via adenosine and redox status following hepatic ischaemia reperfusion in rats. Clin Sci (Lond) 115: 69-77, 2008.

46. Taniguchi M, Magata S, Suzuki T, Shimamura T, Jin MB, Iida J, Furukawa $\mathrm{H}$ and Todo S: Dipyridamole protects the liver against warm ischemia and reperfusion injury. J Am Coll Surg 198: 758-769, 2004

47. Maggio AJ Jr, Das S, Smith RB and Kaufman JJ: Renal preservation with inosine. Urology 16: 343-345, 1980.

48. Tilser I, Martinkova J and Chladek J: The effect of metipranolol and inosine on total hepatic ischemia of rats in vivo. Sb Ved $\mathrm{Pr}$ Lek Fak Karlovy Univerzity Hradci Kralove 36: 25-29, 1993. 